\title{
Níveis de proteína em rações com milho ou sorgo para codornas japonesas
}

\author{
Maciel, M.P. ${ }^{\circledR}$; Moura, V.H.S. ${ }^{\text {; }}$ Aiura, F.S. ${ }^{1}$; Arouca, C.L.C. ${ }^{\text {; }}$ Souza, L.F.M. ${ }^{2}$; Silva, D.B. ${ }^{1}$ e Said, J.L.S. ${ }^{1}$
}

'Departamento de Ciências Agrárias. Universidade Estadual de Montes Claros. Janaúba. Minas Gerais. Brasil.

${ }^{2}$ Granja Avis. Janaúba. Minas Gerais. Brasil.

PaLAVRAS CHAVE ADICIONAIS

Alimento alternativo.

Desempenho.

Qualidade de ovos.

\section{RESUMO}

Objetivou-secom esta pesquisa avaliar níveis de proteína bruta em raçães com milho ou sorgo sobre o desempenho e qualidade de ovos de codornas japonesas na fase de postura. Foram utilizadas 320 codornas com idade inicial de 14 semanas. $O$ delineamento experimental uilizado foi o inteiramente casualizado em esquema fatorial $2 \times 5$, sendo 2 alimentos (milho e sorgo) e 5 níveis de proteína bruta $(16,18,20,22$ e 24\%), totalizando 10 tratamentos com 4 repetições e 8 aves por unidade experimental. Foram avaliadas as variáveis de desempenho e de qualidade dos ovos. Houve efeito quadrático dos níveis de proteína bruta (PB) sobre o consumo de ração, conversão alimentar por dúzia e por massa, peso dos ovos, índice de albúmen e peso específico. A ração com milho proporcionou melhor produção de ovos e de ovos comercializáveis em relação à ração com sorgo quando o nível de PB utilizado foi de 16\%. Houve efeito quadrático de níveis de PB sobre a produção de ovos totais e comercializáveis somente das aves que receberam ração com sorgo. Concluise que o sorgo pode substituir na totalidade o milho nas rações para codornas japonesas. Rações com sorgo devem conter $21,7 \%$ de proteína bruta para maior produção de ovos e 19,38\% de proteína bruta para maior peso específico dos ovos.

\section{Protein levels in rations with corn or sorghum for Japanese quails}

\section{SUMMARY}

The objective of this research was to evaluate crude protein levels in corn or sorghum rations on performance and quality of Japanese quail eggs in the laying phase. We used 320 quails with an initial age of 14 weeks. The experimental design was completely randomized in a $2 \times 5$ factorial scheme, with 2 foods (maize and sorghum) and 5 crude protein levels $(16,18,20,22$ and 24\%), totaling 10 treatments with 4 replicates and 8 Birds per experimental unit. The performance and egg quality variables were evaluated. There was a quadratic effect of crude protein (CP) levels on feed intake, feed conversion per dozen and by mass, egg weight, albumen index and specific weight. The corn ration provided better marketable egg and egg production in relation to the sorghum ration when the $\mathrm{CP}$ level used was $16 \%$. There was a quadratic effect of $\mathrm{CP}$ levels on the production of total and marketable eggs only of the birds that received feed with sorghum. It can be concluded that sorghum may substitute maize in Japanese quails. Sorghum feed should contain $21.7 \%$ crude protein for higher egg production and $19.38 \%$ crude protein for higher egg weight.

\section{INTRODUÇÃO}

Apesar das codornas japonesas apresentarem baixo consumo de ração em relação a outras aves, os custos para produção de seus ovos são afetados pela alimentação, pois são exigentes nutricionalmente (Garcia et al., 2012). A utilização de alimentos alternativos ao milho, além de diminuir custos, é uma oportunidade de encontrar fontes energéticas que o substituam, sem que ocorram prejuízos no desempenho e na qualidade dos ovos das codornas.
O sorgo, por suas características nutricionais semelhantes ao milho, tem sido uma alternativa como ingrediente energético. $\mathrm{O}$ sorgo geralmente apresenta preço inferior e é resistente à seca (Menezes et al., 2015). Possui maior teor proteico que o milho, porém com menores teores que este último em energia, lisina e metionina. A principal preocupação em relação ao sorgo é o seu teor de taninos, pois seus componentes fenólicos possuem propriedades de formarem complexos, principalmente com proteínas, podendo reduzir a digestibilidade dos aminoácidos e da matéria seca em 
até $10 \%$ (Leeson \& Summers, 2001). Porém, com o melhoramento genético do sorgo, os problemas gerados pela presença do tanino foram minimizados, devido à produção de variedades de baixo tanino destinadas à produção de grãos para rações de animais não ruminantes (Moreno et al., 2007).

Dos nutrientes mais importantes para o desempenho e produção de ovos, deve-se destacar a proteína bruta, visto que a exigência pela mesma varia de acordo com a taxa de crescimento e a produção de ovos das aves. A proteína, quando fornecida em níveis abaixo do exigido pela categoria animal promove redução do crescimento e produção de ovos devido ao fato do desvio de parte da mesma para outras funções, prejudicando consequentemente o desenvolvimento corporal e a produção. Ao contrário, se é fornecida em excesso, pode limitar o desempenho, pois o catabolismo aminoacídico exige gasto extra de energia para excreção de nitrogênio na forma de ácido úrico (Jordão Filho et al., 2006). Além disso, segundo Silva et al. (2006) o custo de produção de codornas aumenta com o alto preço das fontes proteicas da ração. A proteína é o nutriente mais caro podendo chegar a $25 \%$ dos custos com alimentação e seu balanceamento adequado deve melhorar a competitividade e o rendimento econômico das criações de codornas.

Diante do exposto, objetivou-se com esta pesquisa avaliar diferentes níveis de proteína bruta em rações contendo milho ou sorgo sobre o desempenho e a qualidade de ovos de codornas japonesas em fase postura.

\section{MATERIAL E MÉTODOS}

O experimento foi conduzido nas instalações de uma granja comercial, localizada na zona rural de Nova Porteirinha, Minas Gerais, com duração de 84 dias, dividido em quatro períodos de 21 dias. Foram utilizadas 320 codornas japonesas (Coturnix coturnix japonica), com idade inicial de 14 semanas, sendo as mesmas alojadas em galpão convencional para codornas. Utilizou-se gaiolas equipadas com comedouros tipo calha, bebedouros tipo nipple e bandejas coletoras de excretas. $\mathrm{O}$ fornecimento de ração e água foi à vontade durante todo o período experimental. A temperatura e umidade no interior do galpão foram monitoradas duas vezes ao dia, as 8 e 16 horas por meio de termômetros de bulbo seco e úmido posicionados próximos às gaiolas. Foram observados durante o período experimental média de temperatura e umidade de $27,3^{\circ} \mathrm{C}$ e $57,7 \%$, respectivamente.

O delineamento experimental utilizado foi o inteiramente casualizado em esquema fatorial $2 \times 5$, sendo dois ingredientes (milho e sorgo) e cinco níveis de proteína bruta $(16,18,20,22$ e $24 \%)$, totalizando dez tratamentos com quatro repetições e oito aves por unidade experimental. As rações fornecidas foram formuladas conforme recomendações de Silva \& Costa (2009) para codornas japonesas em fase de postura. Os ingredientes e a composição nutricional calculada das rações experimentais estão demonstrados nas tabelas I e II.

As características de desempenho avaliadas foram: porcentagem de postura e de ovos comercializáveis, consumo de ração, conversão alimentar por dúzia e por massa de ovos e peso dos ovos. A produção de ovos foi registrada diariamente, pela manhã, e no final de cada período foram calculadas as porcentagens de postura. O consumo de ração foi obtido através da pesagem da ração fornecida e da sobra, ao final de cada período. A conversão alimentar por massa foi determinada através da relação entre a ração consumida e a massa de ovos produzida dentro do período, sendo a massa calculada multiplicando-se o número de ovos produzidos pelo peso médio dos ovos. A conversão alimentar por dúzia foi calculada pela relação entre o consumo de ração e a quantidade de dúzias de ovos produzida no período. A porcentagem de ovos comercializáveis (OC) foi obtida através da fórmula: $\mathrm{OC}=$ total de ovos íntegros / total de ovos produzidos x 100, sendo ovos íntegros aqueles sem defeitos (ovos com trincas, quebras, deformação, cascas finas ou sem casca e, muito grandes, acima de $12 \mathrm{~g}$, ou muito pequenos, abaixo de $10 \mathrm{~g})$.

As características de qualidade de ovos (peso específico, índices de gema e albúmen, unidade Haugh e porcentagem de casca e espessura de casca) foram avaliadas nos três últimos dias de cada período. $\mathrm{O}$ peso específico foi obtido por imersão de todos os ovos íntegros de cada parcela em baldes com diferentes soluções salinas $(\mathrm{NaCl})$, cujas densidades variaram de 1,055 a 1,095g/ $\mathrm{cm}^{3}$, com intervalos de $0,004 \mathrm{~g} / \mathrm{cm}^{3}$. Para a obtenção da altura e diâmetro de gema e albúmen foram amostrados 3 ovos por parcela, os quais foram devidamente identificados, pesados e quebrados sobre superfície plana. As medidas foram realizadas com paquímetro digital Mitutoyo, precisão de $0,1 \mathrm{~mm}$ (0,1-12mm). Em seguida, os índices de gema e albúmen foram determinados dividindo-se a altura e o diâmetro dos respectivos componentes. A unidade Haugh foi calculada utilizando-se a fórmula desenvolvida por Card \& Nesheim (1968): $\mathrm{UH}=100 \log (\mathrm{H}+7,57-1,7$ $x \mathrm{PO}^{0,37}$, sendo: $\mathrm{H}=$ altura de albúmen e $\mathrm{PO}=$ peso do ovo. A porcentagem de casca foi obtida por meio da relação percentual entre o peso médio dos ovos e o peso médio das cascas secas. As mesmas cascas foram utilizadas na determinação da espessura com um micrômetro digital Mitutoyo com precisão de 0,001mm (0,001-25,000mm), tomando-se 3 medidas da região equatorial de cada casca, obtendo-se uma média representativa.

Os dados foram submetidos à análise de variância e, quando significativa, as médias dos ingredientes foram comparadas pelo teste $\mathrm{F}(5 \%)$ e as médias dos níveis de proteína bruta submetidas à análise de regressão $(5 \%)$ utilizando o programa computacional SISVAR, desenvolvido por Ferreira (2011).

\section{RESULTADOS E DISCUSSÃO}

As variáveis consumo de ração, conversão alimentar por dúzia, conversão alimentar por massa e peso de ovos foram afetadas significativamente pelos diferentes níveis de proteína bruta (PB) e houve interação entre ingredientes e níveis de PB para as variáveis produção de ovos e ovos comercializáveis (Tabela III). 
Tabela I. Ingredientes e composição nutricional calculada das rações experimentais com milho para codornas japonesas em postura (Ingredients and nutritional composition calculated from the experimental diets with maize for laying Japanese quails).

\begin{tabular}{|c|c|c|c|c|c|}
\hline \multirow{2}{*}{ Ingrediente } & \multicolumn{5}{|c|}{ Nível de proteína (\%) } \\
\hline & 16 & 18 & 20 & 22 & 24 \\
\hline Milho grão & 61,82 & 55,64 & 48,68 & 44,53 & 42,11 \\
\hline Soja farelo $45 \%$ & 19,78 & 25,89 & 31,85 & 37,05 & 41,23 \\
\hline Calcário & 6,70 & 6,70 & 6,70 & 6,70 & 6,71 \\
\hline Inerte & 4,50 & 4,00 & 4,00 & 2,78 & 1,12 \\
\hline Óleo de soja & 2,03 & 2,99 & 4,22 & 4,50 & 4,50 \\
\hline Farinha de sangue & 2,00 & 2,00 & 2,00 & 2,00 & 2,00 \\
\hline Fosfato bicálcico & 1,45 & 1,40 & 1,35 & 1,28 & 1,23 \\
\hline Sal comum & 0,51 & 0,51 & 0,51 & 0,51 & 0,51 \\
\hline Suplem. vitamínico e mineral ${ }^{1}$ & 0,50 & 0,50 & 0,50 & 0,50 & 0,50 \\
\hline DL-Metionina & 0,27 & 0,22 & 0,17 & 0,12 & 0,08 \\
\hline L-Lisina HCL & 0,26 & 0,08 & 0,00 & 0,00 & 0,00 \\
\hline L-Treonina & 0,14 & 0,05 & 0,00 & 0,00 & 0,00 \\
\hline \multirow[t]{2}{*}{ Total } & 100,0 & 100,0 & 100,0 & 100,0 & 100,0 \\
\hline & \multicolumn{5}{|c|}{ Nível nutricional calculado } \\
\hline Proteína bruta (\%) & 16,0 & 18,0 & 20,0 & 22,0 & 24,0 \\
\hline Energia metabolizável (kcal/kg) & 2.800 & 2.800 & 2.800 & 2.800 & 2.800 \\
\hline Cálcio (\%) & 2,96 & 2,96 & 2,96 & 2,96 & 2,96 \\
\hline Fósforo disponível & 0,36 & 0,36 & 0,36 & 0,36 & 0,36 \\
\hline Sódio (\%) & 0,23 & 0,23 & 0,23 & 0,23 & 0,23 \\
\hline Metionina total $(\%)$ & 0,51 & 0,49 & 0,46 & 0,44 & 0,42 \\
\hline Metionina digestível (\%) & 0,51 & 0,46 & 0,44 & 0,41 & 0,39 \\
\hline Metionina + cistina total $(\%)$ & 0,77 & 0,77 & 0,78 & 0,78 & 0,80 \\
\hline $\begin{array}{l}\text { Metionina + cistina digestível } \\
(\%)\end{array}$ & 0,70 & 0,70 & 0,70 & 0,70 & 0,70 \\
\hline Lisina total $(\%)$ & 1,06 & 1,06 & 1,15 & 1,29 & 1,42 \\
\hline Lisina digestível (\%) & 0,95 & 0,95 & 1,03 & 1,15 & 1,28 \\
\hline Treonina total (\%) & 0,77 & 0,78 & 0,81 & 0,77 & 0,96 \\
\hline Treonina digestível (\%) & 0,67 & 0,67 & 0,69 & 0,77 & 0,84 \\
\hline Triptofano total (\%) & 0,19 & 0,23 & 0,26 & 0,30 & 0,32 \\
\hline Triptofano digestível (\%) & 0,18 & 0,20 & 0,23 & 0,26 & 0,29 \\
\hline
\end{tabular}

${ }^{1}$ Níveis de garantia (por kg do produto): 70.000 mg de zinco (mín.); 1.500 mg de iodo (mín); 8.500 mg de cobre (mín.); 75.000 mg de manganês (mín.); 50.000 mg de ferro (mín.); 200 mg de cobalto; 1.000 mg de ácido fólico; $15.620 \mathrm{mg}$ de ácido pantotênico; $100 \mathrm{mg}$ de biotina; $39.800 \mathrm{mg}$ de niacina; $7.000 .000 \mathrm{UI}$ de vit. A; $2.000 \mathrm{mg}$ de vit. B1; $50.000 \mathrm{mg}$ de vit. E; $3.000 \mathrm{mg}$ de vit. B12; $4.000 \mathrm{mg}$ de vitamina B2; 3.000 mg de vit. B6; 2.100 .000 Ul de vit. D3; 2.000 mg de vit. K3; 200 mg de selênio; 100.000 mg de antioxidante.

As codornas que receberam a ração com milho e $16 \%$ de PB apresentaram a maior produção em relação à ração com sorgo, com a mesma porcentagem de PB. Este resultado pode ser atribuído ao fato desta ração ter em sua composição maior quantidade de sorgo que as demais. Com resultado semelhante a presente pesquisa, Moreno et al.(2007) também observaram menor produção de ovos de poedeiras leves que receberam ração com sorgo e $16 \%$ de PB. Os autores atribuem este resultado à possível ação negativa de taninos presentes no sorgo, o que pode reduzir a digestibilidade dos aminoácidos e da matéria seca em até $10 \%$ (Leeson \& Summers, 2001).

Quando foi utilizada a ração com sorgo com os demais níveis $(18$, 20, 22 e 24\% de PB) não houve prejuízo à produção de ovos quando comparada à ração com milho. Moura et al. (2010) e Moura et al.(2011) também não observaram diferenças na produção de ovos de codornas japonesas que receberam ração com sorgo e $19 \%$ de PB. Estes resultados mostram que o sorgo pode ser utilizado para codornas, porém com um nível de PB mais alto.

A produção de ovos das codornas que consumiram a ração com sorgo apresentou comportamento quadrático (Figura 1), sendo a maior média observada com um nível estimado de $20,75 \%$ de PB. Jordão Filho et al. (2006) afirmam que, quando a PB é fornecida para poedeiras em níveis mínimos a mesma gera redução na produção de ovos, por conta do desvio de parte desta para funções mais vitais, prejudicando a produção. 
Tabela II. Ingredientes e composição nutricional calculada das rações experimentais com sorgo para codornas japonesas em postura (Ingredients and calculated nutritional composition of experimental diets with sorghum for Japanese quails in posture).

\begin{tabular}{|c|c|c|c|c|c|}
\hline \multirow{2}{*}{ Ingredientes } & \multicolumn{5}{|c|}{ Nível de proteína (\%) } \\
\hline & 16 & 18 & 20 & 22 & 24 \\
\hline Sorgo baixo tanino & 62,62 & 57,37 & 53,71 & 50,00 & 43,33 \\
\hline Soja farelo $45 \%$ & 17,84 & 23,93 & 29,63 & 34,70 & 40,51 \\
\hline Calcário & 6,74 & 6,74 & 6,74 & 6,75 & 6,73 \\
\hline Inerte & 4,00 & 3,07 & 1,38 & 0,00 & 0,00 \\
\hline Óleo de soja & 3,52 & 4,00 & 4,00 & 4,00 & 5,00 \\
\hline Farinha de sangue & 2,00 & 2,00 & 2,00 & 2,00 & 2,00 \\
\hline Fosfato bicálcico & 1,41 & 1,36 & 1,30 & 1,24 & 1,22 \\
\hline Sal comum & 0,52 & 0,52 & 0,52 & 0,51 & 0,51 \\
\hline Suplem. vitamínico e mineral ${ }^{1}$ & 0,50 & 0,50 & 0,50 & 0,50 & 0,50 \\
\hline DL-Metionina & 0,36 & 0,26 & 0,20 & 0,27 & 0,11 \\
\hline L-Lisina HCL & 0,35 & 0,16 & 0,00 & 0,00 & 0,07 \\
\hline L-Treonina & 0,19 & 0,09 & 0,00 & 0,00 & 0,00 \\
\hline \multirow[t]{2}{*}{ Total } & 100 & 100 & 100 & 100 & 100 \\
\hline & \multicolumn{5}{|c|}{ Nível nutricional calculado } \\
\hline Proteína bruta (\%) & 16,0 & 18 & 20 & 22 & 24 \\
\hline Energia metabolizável (kcal/kg) & 2.800 & 2.800 & 2.800 & 2.800 & 2.800 \\
\hline Cálcio (\%) & 2,96 & 2,96 & 2,96 & 2,95 & 2,95 \\
\hline Fósforo disponível & 0,35 & 0,36 & 0,36 & 0,35 & 0,35 \\
\hline Sódio (\%) & 0,23 & 0,23 & 0,23 & 0,23 & 0,23 \\
\hline Metionina total (\%) & 0,53 & 0,51 & 0,48 & 0,57 & 0,43 \\
\hline Metionina digestível (\%) & 0,51 & 0,48 & 0,45 & 0,54 & 0,39 \\
\hline Metionina + cistina total $(\%)$ & 0,77 & 0,77 & 0,78 & 0,89 & 0,79 \\
\hline Metionina + cistina digestível (\%) & 0,70 & 0,70 & 0,70 & 0,81 & 0,70 \\
\hline Lisina total $(\%)$ & 1,04 & 1,06 & 1,09 & 1,22 & 1,43 \\
\hline Lisina digestível (\%) & 0,95 & 0,95 & 0,97 & 1,09 & 1,29 \\
\hline Treonina total (\%) & 0,78 & 0,77 & 0,77 & 0,85 & 0,93 \\
\hline Treonina digestível (\%) & 0,67 & 0,67 & 0,66 & 0,73 & 0,81 \\
\hline Triptofano total (\%) & 0,20 & 0,24 & 0,25 & 0,30 & 0,33 \\
\hline Triptofano digestível (\%) & 0,18 & 0,21 & 0,24 & 0,27 & 0,29 \\
\hline
\end{tabular}

${ }^{1}$ Níveis de garantia (por kg do produto): 70.000 mg de zinco (mín.); 1.500 mg de iodo (mín); 8.500 mg de cobre (mín.); 75.000 mg de manganês (mín.); 50.000 mg de ferro (mín.); 200 mg de cobalto; 1.000 mg de ácido fólico; 15.620 mg de ácido pantotênico; 100 mg de biotina; $39.800 \mathrm{mg}$ de niacina; 7.000 .000 UI de vit. A; $2.000 \mathrm{mg}$ de vit. B1; $50.000 \mathrm{mg}$ de vit. E; $3.000 \mathrm{mg}$ de vit. B12; $4.000 \mathrm{mg}$ de vitamina B2; $3.000 \mathrm{mg}$ de vit. B6; $2.100 .000 \mathrm{UI}$ de vit. D3; $2.000 \mathrm{mg}$ de vit. K3; $200 \mathrm{mg}$ de selênio; $100.000 \mathrm{mg}$ de antioxidante.

Por outro lado, o excesso deste nutriente pode limitar o desempenho das aves, pois o catabolismo aminoacídico requer gasto extra de energia para excreção de nitrogênio na forma de ácido úrico.

Observa-se na literatura grande variação em relação à recomendação de $\mathrm{PB}$ em rações com milho para codornas japonesas. Silva et al. (2012) encontraram, em revisão sobre exigências nutricionais para codornas, recomendações entre 16 e $25 \%$ de PB e, segundo os autores, está variação talvez esteja relacionada a diferenças genéticas, experimentais ou climáticas, que afetariam o desempenho das codornas japonesas. Embasando este comentário, Pinto et al.(2002), Freitas et al.(2005), Silva \& Costa (2009) e Lima et al.(2014) recomendaram níveis bem variados para máximo desempenho, sendo
$22,42 \% ; 18,00 \% ; 20,00 \%$ e $26,00 \%$ de $\mathrm{PB}$, respectivamente.

Houve efeito dos níveis de PB sobre o consumo de ração das codornas, independente do ingrediente testado, sendo o máximo valor obtido com $20,43 \%$ de PB (Figura 2). Semelhante a esta pesquisa, Pinto et al. (2002) também observaram comportamento quadrático do consumo, sendo o valor máximo encontrado com $21,80 \%$ de PB. Segundo estes autores, as aves poedeiras possuem habilidade limitada em estocar proteína, sendo dependentes da ingestão diária, existindo ainda, uma correlação positiva entre PB da ração e consumo. Esta relação pôde ser observada na presente pesquisa no comportamento da postura das codornas que consumiram a ração com sorgo, pois as mesmas apresentaram maior consumo com uma porcentagem de $\mathrm{PB}$ 

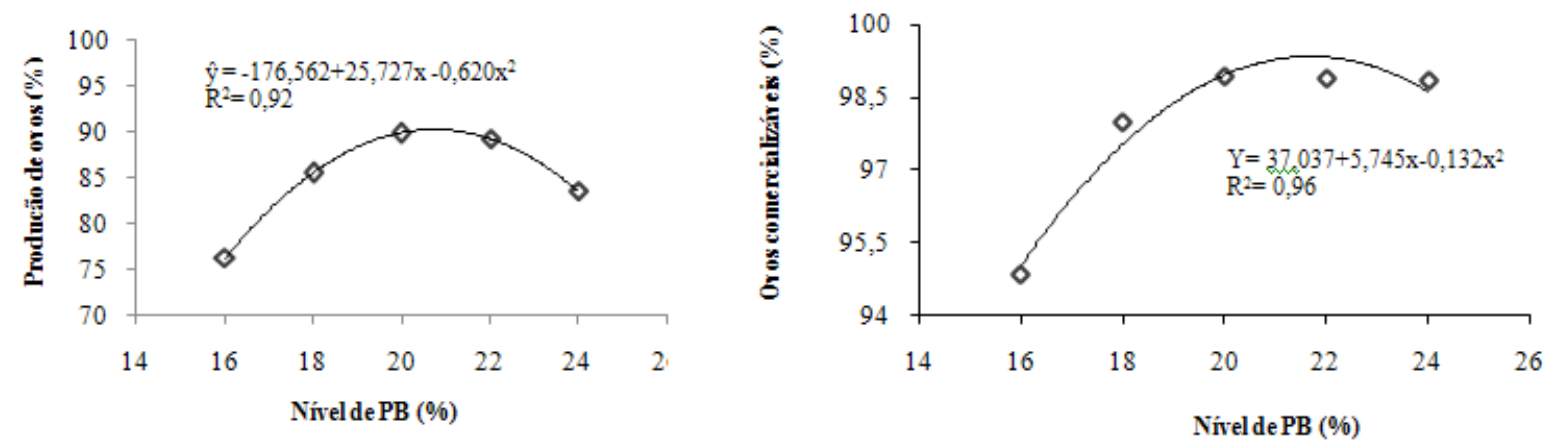

Figura 1. Producão de ovos e porcentagem de ovos comercializáveis de codomas japonesas de acordo com o nível de PB na ração com sorgo (Egg production and percentage of marketable eggs of Japanese codomas according to the level of PB in the ration with sorghum).

muito próxima $(20,75 \%)$ àquela na qual apresentaram maior produção de ovos $(20,43 \%)$.

O peso dos ovos não foi influenciado pelos ingredientes testados (Tabela III). Este resultado concorda com aqueles obtidos por Moreno et al. (2007) e Assuena et al. (2008), com poedeiras leves, e Moura et al. (2010) com codornas japonesas que observaram que a substituição do milho pelo sorgo é viável, pois não interfere, entre outras variáveis, no peso dos ovos.

Os níveis de PB das rações influenciaram o peso dos ovos, o qual apresentou comportamento quadrático (Figura 2), sendo o valor máximo observado com a utilização de $21,88 \%$ de PB. Este resultado é diferente daquele encontrado por Pinto et al.(2002) que observaram comportamento linear no peso dos ovos de codornas japonesas com a utilização de até $24 \%$ de PB; porém assemelham-se àqueles verificados por Freitas et al.(2005) e por Lima et al. (2014) que encontraram aumento do peso dos ovos de codornas com o nível de $21,16 \%$ e $21,65 \%$, respectivamente. O conhecimento das exigências proteicas para poedeiras em fase de produção é de fundamental importância, uma vez que o peso dos ovos e de seus constituintes é dependente da ingestão de proteínas. Para poedeiras, o nível de proteína na ração é importante devido à grande quantidade necessária deste nutriente, para a formação do material da gema e, especialmente, do albúmen do ovo. Poedeiras alimentadas com adequado nível de PB na ração, em comparação àquelas alimentadas com níveis subótimos, apresentam maior taxa de síntese proteica no fígado e no oviduto, principais órgãos envolvidos na síntese de PB que constituem a gema
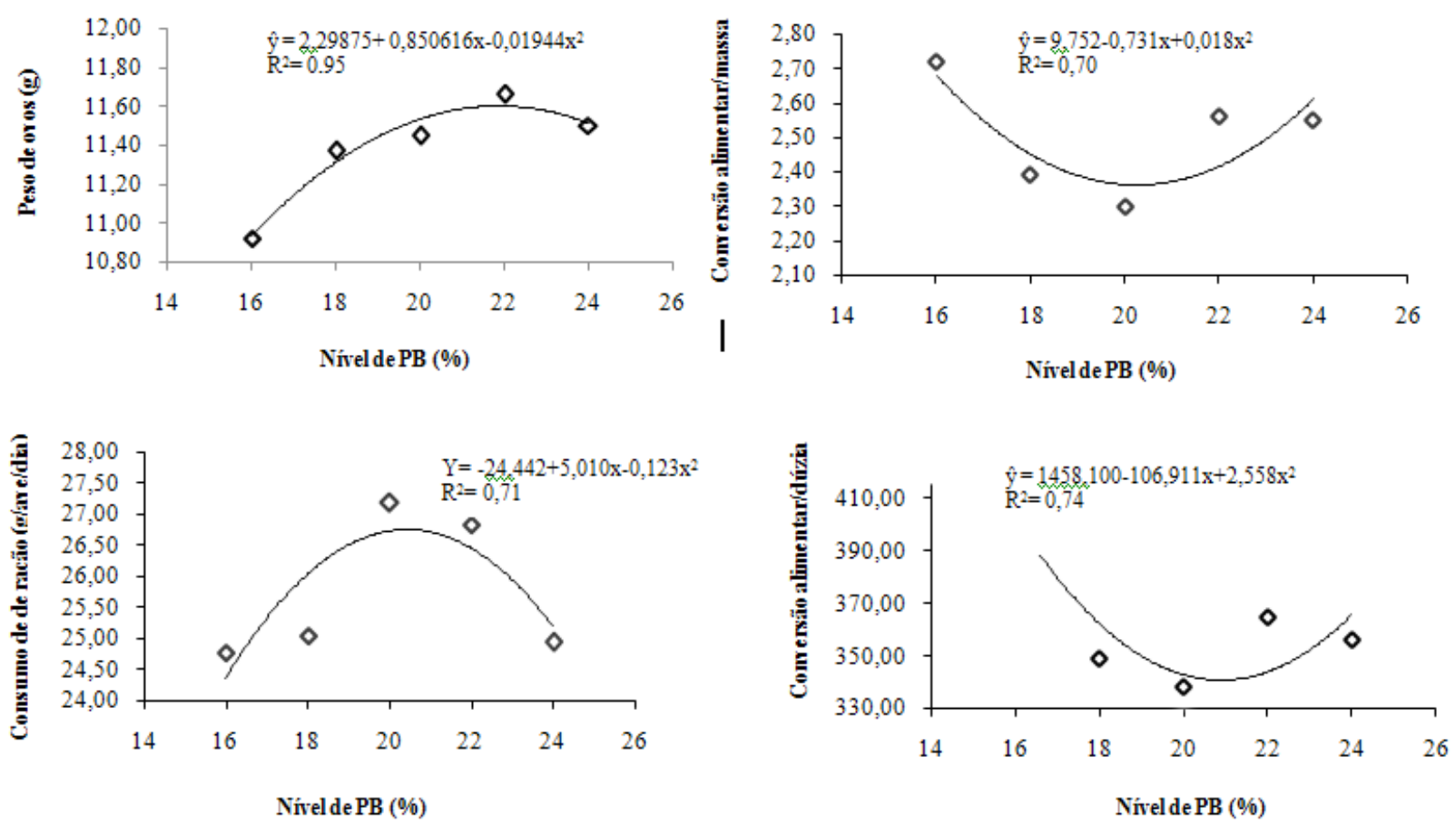

Figura 2. Peso de ovos, conversao alimentar/massa, conversao alimentar/dúzia e consumo de ração de codomas japonesas de acordo como nível de PB das rações (Egg weight, feed/mass conversion, food conversion/dozen and feed intake Japanese Codomas according to the CP level of the rations). 
e o albúmen do ovo, respectivamente (Muramatsu et al., 1987).

Segundo Freitas et al. (2005), embora os ovos de codornas sejam, na maioria, comercializados por unidade e não por peso, os baixos níveis de $\mathrm{PB}$ podem comprometer o tamanho dos ovos, deixando-os fora do padrão, o que pode prejudicar a sua comercialização.

A conversão por massa de ovos apresentou comportamento quadrático (Figura 2) resultado da influência dos níveis de $\mathrm{PB}$ das rações, sendo que o nível que provocou o menor valor foi de $20,25 \%$. A conversão por massa é resultado da relação entre consumo e massa de ovos, então este resultado era esperado, pois estas duas variáveis apresentaram o mesmo comportamento. Discordando do presente trabalho Pinto et al. (2002) não encontraram diferenças entre os níveis de proteína testados para conversão por massa e Ribeiro et al. (2003) e Freitas et al. (2005) verificaram melhores resultados quando a ração para codornas tinha $23 \%$ e $22 \%$ de $\mathrm{PB}$, respectivamente.

Semelhante ao observado no presente estudo, Moura et al. (2010) e Moura et al. (2011) também não observaram diferenças na conversão por massa de ovos de codornas que receberam rações com milho ou com sorgo. Os resultados destes autores indicaram que o sorgo pode substituir totalmente o milho em rações para codornas japonesas, sem prejuízos para o desempenho.

Os níveis de PB também influenciaram significativamente a conversão alimentar por dúzia de ovos (Figura 2). Essa variável apresentou comportamento quadrático, sendo o menor valor encontrado quando na utilização de 20,89\% de PB. O comportamento desta variável seguiu a tendência do consumo de ração e da produção de ovos, o que era esperado visto que as relações entre estes dois últimos influenciam diretamente, pois através da relação dos mesmos são encontrados os valores de conversão por dúzia. No entanto, Lima et al.(2014), apesar de encontrarem efeito dos níveis de PB $(14,17,20,23$ e $26 \%)$ sobre o consumo e a produção de codornas japonesas, não observaram efeito dos níveis sobre a conversão por dúzia.

Os ingredientes testados não influenciaram a conversão alimentar por dúzia de ovos. Este resultado concorda com aqueles encontrados por Moura et al. (2010) e Moura et al. (2011), os quais indicam o sorgo como substituto ao milho nas rações de codornas, sem afetar a conversão alimentar.

Ovos comercializáveis (OC) são aqueles que serão repassados aos consumidores e, por isso, não devem apresentar nenhum tipo de defeito como trincas, quebras, gema dupla, deformidades, casca fina ou sem casca, coloração branca ou preta e, também, não ser exageradamente grandes ou pequenos.

A porcentagem de ovos comercializáveis (OC) sofreu interação dos ingredientes e dos níveis de PB das rações. Quando utilizado o nível de $16 \%$, a ração com milho proporcionou maior média de OC em comparação à ração com sorgo. Já os níveis de PB influenciaram somente a produção de OC das codornas que receberam as rações com sorgo, com as médias apresentando comportamento quadrático, sendo a maior porcentagem encontrada com o nível de 21,69\% de PB (Figura 1). Muniz et al. (2015), não encontraram diferenças significativas entre em rações comerciais para codornas com diferentes níveis proteicos (19, 20 e 21\%), porém utilizando milho na ração.

Na tabela IV podem ser observados os resultados das variáveis de qualidade de ovos. As variáveis porcentagem e espessura de casca e índice de gema não foram alteradas pelas rações. Houve efeito significativo dos níveis de PB sobre a variável índice de albúmen e dos ingredientes sobre a Unidade Haugh. O peso específico foi influenciado pelos ingredientes e pelos níveis de $\mathrm{PB}$.

A porcentagem e a espessura de casca não foram influenciadas pelos níveis de PB, o que, de certa forma, já era esperado, pois este nutriente não exerce influência direta sobre a composição da casca. Ri et al. (2005), avaliando vários níveis de PB (16, 18, 20, 22, 24 e 26\%) para codornas japonesas, também não observaram efeito na porcentagem de casca. Segundo Faria \& Santos (2005) as exigências de proteína para codornas estão relacionadas principalmente à produção e peso dos ovos (composição de constituintes internos), mantença, crescimento de tecidos corporais e empenamento. Discordando dos resultados do presente trabalho, Pinto et
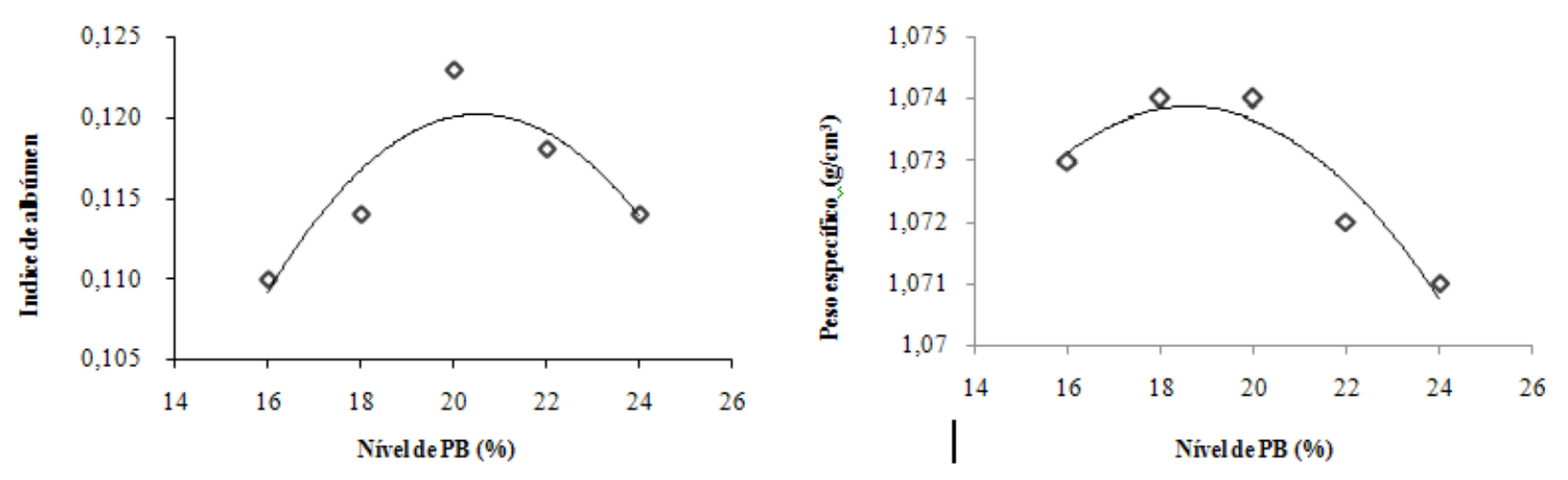

Figura 3. Índice albúmen e peso específico $(\mathrm{g} / \mathrm{cm} 3)$ de ovos de codornas japonesas de acordo com o nível de $\mathrm{PB}$ das rações (Albumen index and specific weight $(\mathrm{g} / \mathrm{cm} 3)$ of Japanese quail eggs according to the CP level of the diets). 
Tabela IV. Qualidade de ovos de codornas japonesas de acordo com o ingrediente e o nível de proteína bruta (Quality of Japanese quail eggs according to the ingredient and the level of crude protein)

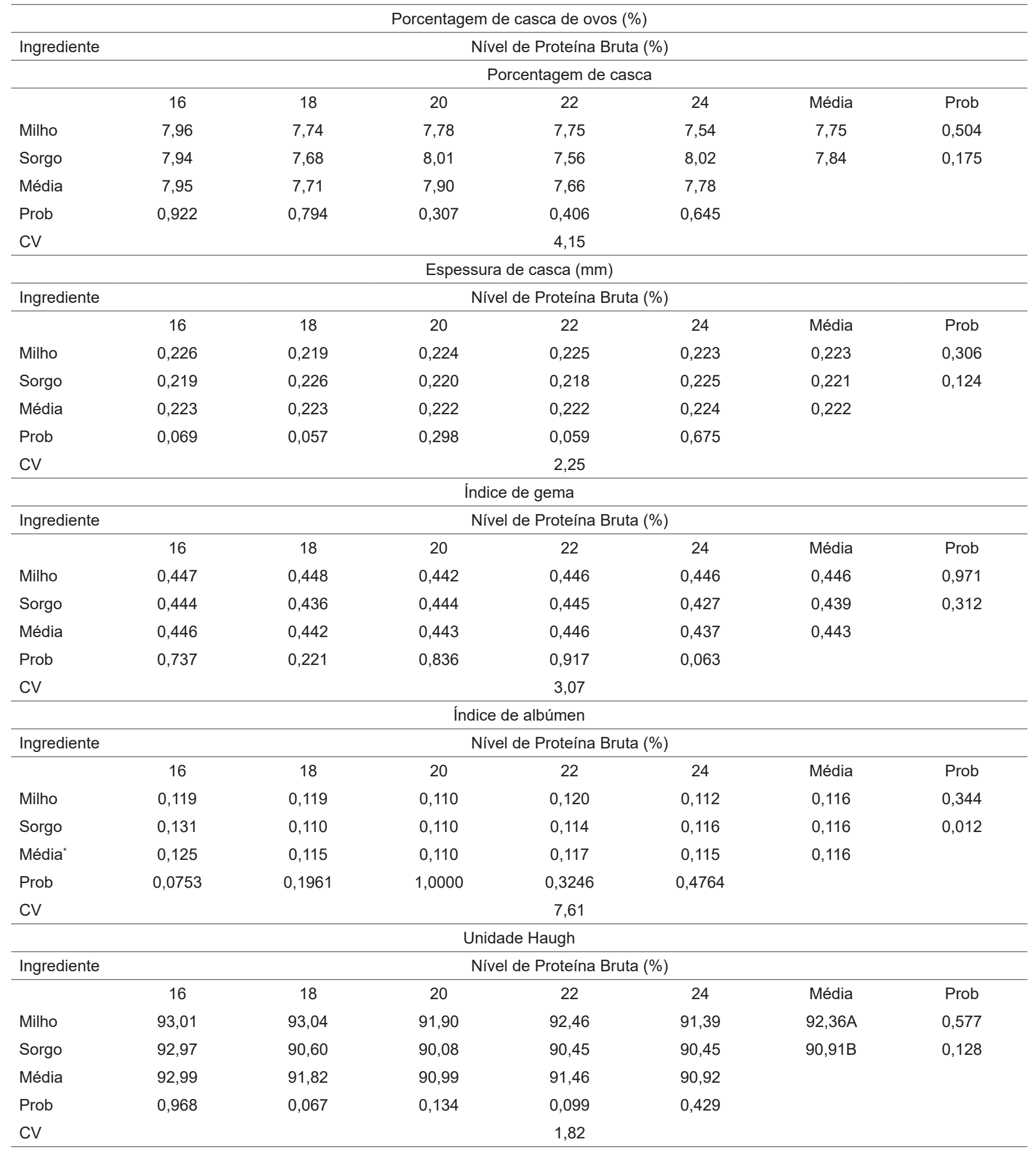

\begin{tabular}{|c|c|c|c|c|c|c|c|}
\hline \multicolumn{8}{|c|}{ Peso específico $\left(\mathrm{g} / \mathrm{cm}^{3}\right)$} \\
\hline Ingrediente & \multicolumn{7}{|c|}{ Nível de Proteína Bruta (\%) } \\
\hline & 16 & 18 & 20 & 22 & 24 & Média & Prob \\
\hline Milho & 1,074 & 1,071 & 1,074 & 1,072 & 1,071 & $1,073 \mathrm{~A}$ & 0,016 \\
\hline Sorgo & 1,072 & 1,073 & 1,073 & 1,070 & 1,073 & $1,072 B$ & 0,009 \\
\hline Média* & 1,073 & 1,072 & 1,0735 & 1,071 & 1,072 & 1,072 & \\
\hline CV & & & & 0,11 & & & \\
\hline
\end{tabular}

Médias seguidas de letras diferentes na coluna diferem estatisticamente pelo teste Scott-Knott $(P<0,05)$; 'Efeito quadrático $(P<0,05)$.

Archivos de zootecnia vol. 68, núm. 261, p. 116. 
al.(2002) observaram efeito quadrático dos níveis de PB $(16,18,20,24 \%)$, com o nível ótimo de porcentagem de casca obtido com $21,30 \%$.

Em pesquisa na qual avaliaram rações para codornas japonesas, Faquinello et al. (2004) não observaram efeito deletério na porcentagem e espessura de casca de ovos de codornas quando substituíram 100\% o milho pelo sorgo. Assuena et al. (2008) em estudo com poedeiras comerciais e Moura et al. (2010), com codornas japonesas, recebendo na ração o sorgo substituindo em 100\% o milho, não observaram efeitos negativos na porcentagem e espessura de casca, e na espessura de casca, respectivamente.

A média de espessura de casca encontrada nesta pesquisa foi de 0,222 mm. Segundo Barreto et al. (2007) cascas com espessuras acima de 0,220 indicam ovos de boa qualidade externa. Porém, Albino \& Barreto (2012) ovos com espessura de casca a partir de $0,183 \mathrm{~mm}$ podem ser considerados como normais para codornas japonesas.

Não houve influência dos ingredientes e nem dos níveis de PB sobre o índice de gema. Segundo El-Tarabany (2016) o peso dos ovos se correlaciona positivamente com a altura e diâmetro de gema e, consequentemente, com o índice de gema. Então, era esperado que houvesse variação do índice de gema de acordo com os níveis de PB, pois o peso dos ovos foi influenciado (Tabela III), porém isso não ocorreu. Já o índice de albúmen, foi influenciado pelos níveis de PB, apresentando comportamento quadrático (Figura 3), sendo o nível ótimo de 20,63\%. O albúmen possui em sua constituição basicamente água e proteínas (FAO, 2010), sendo que, a quantidade destas últimas, provavelmente foi aumentada pelos níveis de PB da ração, o que também pode refletido no maior peso dos ovos até o nível de 21,88\%. Segundo Pesti et al. (2005) para a síntese de albúmen a necessidade de proteína e aminoácidos é alta e, portanto, o aumento de tais nutrientes na ração pode ocasionar a elevação da quantidade de albúmen, levando também ao maior tamanho de ovo.

Apesar do peso do ovo e do índice de albúmen terem sido influenciados pelos níveis de $\mathrm{PB}$, isto não refletiu na UH dos ovos da presente pesquisa. Houve efeito significativo apenas para ingredientes, sendo que as codornas alimentadas com a ração com milho, independente do nível de PB utilizado, produziram ovos com maior UH. Discordando deste resultado, Faquinello et al. (2004) avaliando substituição do milho pelo sorgo até o nível de 100\%, não encontraram diferenças significativas para a UH de ovos de codornas. Porém, Costa et al. (2006) observaram que rações com sorgo diminuíram o peso do albúmen dos ovos das codornas. Os autores atribuíram este resultado à possível diferença de digestibilidade de aminoácidos entre milho e sorgo, pois este último promove menor digestibilidade dos aminoácidos metionina e lisina o que pode ter prejudicado a deposição de proteínas nos ovos das codornas.

A UH média observada neste experimento foi de $91,63 \%$. O valor encontrado se encaixa na classificação de ovos de excelente qualidade que, conforme a USDA
(2000), são aqueles que apresentam valores de 72 a 100 de UH.

A variável peso específico foi influenciada somente pelos níveis de PB das rações apresentando comportamento quadrático (Figura 3). O peso específico dos ovos apresenta relação direta com a porcentagem de casca, podendo ser utilizado como método indireto para determinação da qualidade da mesma sendo que, maiores valores desta variável refletem em melhor qualidade da casca (Freitas et al., 2004; Araújo e Albino, 2011). Como já foi comentado anteriormente, a porcentagem de casca não sofreu influência dos níveis de PB, porém foi observado que no nível de 19,38\% deste nutriente o peso específico começou a diminuir. Isso ocorreu provavelmente pelo aumento do peso do ovo, devido ao seu conteúdo, que não foi acompanhado, porém pelo aumento na deposição de casca, o que pode ter levado à piora da qualidade da mesma refletindo na queda das médias de peso específico. Pinto et al.(2002), apesar de não ter avaliado o peso específico, encontrou resultados semelhantes, com aumento do peso do ovo até o nível de $24 \%$ de $\mathrm{PB}$, mas acompanhado de uma queda de porcentagem de casca após o nível de 21,30\%.

A maior parte das irregularidades encontradas nos ovos com defeito na presente pesquisa foi a casca fina $(45,4 \%)$. Este resultado é compatível com os resultados encontrados de peso de ovos e peso específico, pois os ovos aumentaram de tamanho, mas as cascas ficaram mais finas, ocasionando a queda da porcentagem de ovos comercializáveis a partir do nível de $21,69 \%$ de PB.

\section{CONCLUSÕES}

O sorgo pode substituir em $100 \%$ o milho nas rações para codornas japonesas. Porém, rações com sorgo devem conter $21,7 \%$ de proteína bruta para maior produção de ovos e 19,38\% de proteína bruta para maior peso específico dos ovos.

\section{BIBLIOGRAFÍA}

Albino, LFT \& Barreto, SLT 2012, Criação de codornas para produção de ovos e carne.Aprenda fácil, Viçosa, Brasil.

Araújo, WAG \& Albino, LFT 2011, Comercial Incubation. Transworld Research Network, Kerala, Índia, acessado 11 agosto 2017, <https:// issuu.com/researchsignpost/docs/araujo_e-book>.

Assuena, V, Filardi, RS, Junqueira, OM, Casartelli, EM, Laurentiz, AC, \& Duarte, KF2008, 'Substituição do milho pelo sorgo em rações para poedeiras comerciais formuladas com diferentes critérios de atendimento das exigências em aminoácidos', Ciência Animal Brasileira, v.9, n. 1, pp. 93-99

Barreto, SLT, Pereira, CA, Umigi, RT, Rocha, TC, Araújo, MS, Silva, CS\&Torres Filho, RA 2007,'Determinação da exigência nutricional de cálcio de codonras japonesas na fase inicial do ciclo de produção', Revista brasileira de Zootecnia, v.36, n. 1, pp. 68-78

Card, LE \& Nesheim MC 1968, Producción Avícola, Editorial Acribia, Zaragoza, España.

Costa, FGP, Gomes, CAV, Silva, JHV, Goulart, CC \& Dourado, LRB 2006, 'Efeitos da inclusão do extrato oleoso de urucum em rações de poedeiras com substituição total ou parcial do milho pelo sorgo de baixo tanino', Acta Scientiarum. Animal Sciences, v. 28, n. 4, pp. 409-414. El-Tarabany, MS 2016, 'Effect of thermal stress on fertility and egg quality of Japanese quail', Journal of Thermal Biology, v. 61, pp. 38-43. 
Faria, DE \&Santos, LA 2005 'Nutritional requirements of layers'. Palestra apresentada no Segundo Simpósio Internacional sobre Exigências Nutricionais de Aves e Súnos, Viçosa, Brasil, 31 Março.

\section{FAO 2010, Agribusiness Handbook} Poultry Meat and Eggs. FoodandAgriculture Organization of the United Nations, Roma, Itália, acessado 12 agosto 2017, <http://www.fao.org/docrep/012/11175e/al175e.pdfs.

Faquinello, P, Murakam, AE, Cella, PS, Franco, JRG, Sakamoto MI, \& Bruno, LDG 2004, 'Hight tannin sorghum in diets of Japanese Quail (Coturnix coturnixjaponica)', Revista Brasileira de Ciência Avícola, v.6, n.2, pp.81-86

Ferreira, DF 2011 ,'Sisvar: a computerstatisticalanalysis system', Ciência e Agrotecnologia, v. 35, n.6, pp. 1039-1042.

Freitas, ER, Sakomura, NK, Gonzalez, MM\& Barbosa, NAA 2004, 'Comparação de métodos de determinação da gravidade específica de ovos de poedeiras comerciais', Pesquisa Agropecuária Brasileira, v. 39 , n. 5 , p. $509-512$.

Freitas, AC, Fuentes, MFF, Freitas, ER, Sucupira, FS \& Oliveira, BCM 2005, 'Efeito de níveis de proteína bruta e de energia metabolizável na dieta sobre o desempenho de codornas de postura', Revista Brasileira de Zootecnia, v.34, n.3, pp.838-846.

Garcia, AFQM, Murakami, AE, Massuda, EM, Urgnani, FJ, Potença, A, Duarte, CRA \&Eyng, C 2012, 'Milheto na alimentação de codornas japonesas', Revista Brasileira de Saúde e Produção Animal,v. 13, n.1, pp. 150-159

USDA2000,Egg-Grading Manual.Agricultural Handbook Number 75.USDA, Washington, D.C, acessado 12 agosto

2017,<https://www.ams.usda.gov/sites/default/files/media/Egg\%20 Grading\%20Manual.pdf>.

Jordão Filho, J, Silva, JHV, Silva, EL, Ribeiro, MLG, Costa, FGP \& Rodrigues, PB 2006, 'Exigência de lisina para poedeiras semipesadas durante o pico de postura', Revista Brasileira deZootecnia, v.35, (suplemento), pp.1728-1734.

Leeson, S \& Summers, SJD 2001, Scott's Nutrition of the chicken.4 $4^{\mathrm{a}} \mathrm{ed}$. University Books, Ghelf, Canadá.

Lima, RC, Costa, FGP, Goulart, CC, Cavalcante, LE, Freitas, ER, Silva, JHV, Dantas, LS\& Rodrigues VP 2014, 'Exigência de proteína bruta para codornas japonesas (Coturnix coturnix japonica) na fase de postura',Arquivo Brasileiro deMedicina Veterinária e Zootecnia, v.66, n.4, pp. 1234-1242.

Menezes, CB, Ribeiro, ASR, Tardin, FD, Carvalho, AJ, Bastos, EA, Cardoso, MJ, Portugal, AF, Silva, KJ, Santos, CV \& Almeida, FHL 2015, 'Adaptabilidade e estabilidade de linhagens de sorgo em ambientes com e sem restrição hídrica', Revista Brasileira de Milho e Sorgo, v.14, n.1, pp. 101-115.

Moreno, JO, Espínola, GB, Santos, MSV, Freitas, ER, Gadelha, AC \& Silva, FMC. 2007, 'Desempenho e qualidade dos ovos de poedeiras comerciais, alimentadas com dietas contendo sorgo e páprica em substituição ao milho', Acta Animal Science, v. 29, n. 2, pp. 159-163.

Moura, AMA, Fonseca, JB, Rabello, CB, Takata, FN \& Oliveira, NTE 2010, 'Desempenho e qualidade do ovo de codornas japonesas alimentadas com rações contendo sorgo', Revista Brasileira de Zootecnia, v.39, n.2, pp.2697-2702.

Moura, AMA, Takata, FN, Nascimento, GR, Silva, AF, Melo TV, Cecon, PR 2011, 'Pigmentantes naturais em rações à base de sorgo para codornas japonesas em postura', Revista Brasileira de Zootecnia, v. 40, n.11, pp.2443-2449.

Muniz, JCL, Barreto, LT, Viana, GS, Reis, RS, Mencalha, R, Barbosa, LMR \&Ferreira, RC 2015, 'Desempenho e qualidade de ovos de codornas japonesas alimentadas com diferentes rações comerciais', Revista Brasileira de Agropecuária Sustentável, v.5, n. 1, pp.95-100.

Muramatsu, T, Hiramoto, K, Tasaki, I \&Okumura, J 1987, 'Effect of protein starvation on protein turnover in liver, oviduct and whoe body of laying hens', Comparative Biochemistry and Physiology, Part B, v. 87 , n.2, pp. 227-232.

Pesti, GM, Bakalli, RI, Driver, JP, Atencio, A \& Foster, EH 2005, Poultry Nutrition and Feeding, Trafford Publishing, Victoria, Canadá.

Pinto, R, Ferreira, AS \&Albino, LFT 2002, 'Níveis de proteína e energia para codornas japonesas em postura', Revista Brasileira de Zootecnia, v.31, n. 4, pp.1761-1770.

Ri, E, Katsunori, S, Oikawa, T, Kunieda, T \& Uchida, H 2005, 'Effects of dietary protein levels on production and characteristics of Japanese quail eggs', The Journal of Poultry Science, v. 42, pp. 130-139.

Ribeiro, MLG, Silva, JHV, Dantas, MO, Costa, FGP, Oliveira, SF, Jordão Filho, J \&Silva, EL 2003, 'Exigências nutricionais de lisina para codornas durante a fase de produção em função do nível de proteína da ração', Revista Brasileira deZootecnia, v. 32, n.1, pp.156-161.

Silva, EL, Silva, JHV, Jordão Filho, J, Ribeiro, MLG, Costa, FGP \& Rodrigues, PB 2006, 'Redução dos níveis de proteína e suplementação aminoacídica em rações para codornas europeias (Coturnix coturnix coturnix)', Revista Brasileira de Zootecnia, v.35, n. 3, pp.822-829. Silva, JHV \& Costa, FGP 2009, Tabela para codornas japonesas e europeias. $2^{a}$ ed., FUNEP, Jaboticabal, São Paulo.

Silva, JHV, Jordão Filho, J, Costa, FGP, Lacerda, PB, Vargas, DGV \& Lima, MR 2012, 'Exigências nutricionais de codornas', Revista Brasileira de Saúde e Produção Animal, v. 13, n. 13, pp.775-790. 